\title{
MICRODELETION IN THE SRY GENE: CLINICAL MANIFESTATIONS IN A PHENOTYPIC FEMALE PATIENT WITH SWYER SYNDROME
}

\author{
SILVA-VIEIRA M. ${ }^{*}$, SIMÕES-PEREIRA J.1, TEIXEIRA A. ${ }^{2}$ AND PEREIRA C. ${ }^{1}$ \\ 1Endocrinology Department, Instituto Português de Oncologia de Lisboa, Francisco Gentil, 1099-023 Lisbon, Portugal. \\ 2Paediatric Department, Instituto Português de Oncologia de Lisboa, Francisco Gentil, 1099-023 Lisbon, Portugal. \\ *Corresponding Author: Email- mmdvieira@ipolisboa.min-saude.pt
}

Received: February 16, 2014; Accepted: May 27, 2014

\begin{abstract}
steroid production and have a higher risk of developing neoplastic transformation of germ cell (until $75 \%$ ). deletion in Yp11.23 that is responsible for a codifying sequence deletion of the gene. up in endocrinology and oncological outpatient clinic. malignancy, but also for getting a normal pubertal development.

Keywords- ovarian dysgerminoma, gonadal dysgenesis, Swyer syndrome, puberty induction

Running Title: Clinical manifestations of Swyer Syndrome
\end{abstract}

Background: Swyer Syndrome (or pure gonadal dysgenesis [PGD]) is a rare condition characterized by a karyotype 46, $X Y$ in a phenotypic female subject. Deletions in the SRY gene are responsible for $20 \%$ of the cases. These individuals are completely devoid of any gonadal

Case Report: A 14-year-old girl was referred to our centre by her general physician for a large pelvic mass. After going throughout complementary evaluation, the patient was diagnosed with an ovarian dysgerminoma. The patient underwent neo-adjuvant chemotherapy and bilateral gonadectomy. The karyotype of blood sample and tumour was 46, $X Y$ and the study of molecular changes in SRY gene showed a micro

The patient has initiated hormonal therapy with estradiol at 15 (adding a progesterone formulation after breast development was completed), and she has achieved an adult sexual development and the mid-parental height. Nowadays the patient is 23 years-old and maintains follow

Conclusion: The present case emphasizes the importance of a multidisciplinary approach in Swyer Syndrome, not only for preventing gonadal

Citation: Silva-Vieira M., et al. (2014) Microdeletion in the SRY Gene: Clinical Manifestations in a Phenotypic Female Patient with Swyer Syndrome. Medical Case Reports, ISSN: 0976-8726 \& E-ISSN: 0976-8734, Volume 5, Issue 1, pp.-060-062.

Copyright: Copyright@2014 Silva-Vieira M., et al. This is an open-access article distributed under the terms of the Creative Commons Attribution License, which permits unrestricted use, distribution and reproduction in any medium, provided the original author and source are credited.

\section{Introduction:}

Swyer Syndrome (or pure gonadal dysgenesis) is a chromosomal disease characterized by a karyotype $46, X Y$ in a phenotypic female subject. SRY gene deletions are responsible for $20 \%$ of the cases [1]. These individuals are completely devoid of any gonadal steroid production [2] and have a higher risk of developing neoplastic transformation of germ cell (until 75\%) [3].

Because of the peculiarities of this syndrome, related with the failure of setting a normal pubertal development, higher risk of cancer and long-term consequences of the treatment, these patients require a multidisciplinary follow-up, aiming their development into healthy adults.

This case emphasizes the importance of a multidisciplinary approach to patients with Swyer syndrome.

\section{Case Report}

A 14-year-old girl with no personal or familial medical histories came to our centre with lumbar pain, polyuria and pollakiuria. She presented a Tanner B1P3 and a large, fixed and stone-like pelvic mass, without any other changes in observation.

Evaluation included a CT scan, which showed a solid median pelvic mass, with calcifications, that was responsible for ectasia of right kidney and dilatation of the left ureter. Moreover there were retroperitoneal lymphadenopathies. The cytology confirmed a malignant neoplasm with a morphology that suggested a germinal tumour. Laboratorial analysis revealed: a - fetoprotein $3041,9 \mathrm{ng} / \mathrm{ml}(\mathrm{N}<10$ $\mathrm{ng} / \mathrm{ml}), \mathrm{CA} 12553,6 \mathrm{U} / \mathrm{ml}(\mathrm{N}<35 \mathrm{U} / \mathrm{ml}), \mathrm{CEA}<0,5 \mathrm{ng} / \mathrm{ml}(\mathrm{N}<3 \mathrm{ng} /$ $\mathrm{ml}$ ) e $\beta$ HCG 64,6 U/l $(\mathrm{N}<5 \mathrm{U} / \mathrm{l})$.

She underwent neoadjuvant chemotherapy with bleomicin $(60 \mathrm{mg} /$ $\mathrm{m} 2$ ), etoposide $(1400 \mathrm{mg} / \mathrm{m} 2)$ and cisplatin $(400 \mathrm{mg} / \mathrm{m} 2)$ before right gonadectomy. The karyotype of blood sample and tumour was 46, XY and the study of molecular changes in SRY gene showed a micro deletion in Yp11.23 that is responsible for a codifying sequence deletion of the gene. After taking knowledge of this mutation and the associated cancer risk it was decided to complete gonadectomy. 
After treatment: $a$ - fetoprotein $3 \mathrm{ng} / \mathrm{ml}(\mathrm{N}<10 \mathrm{ng} / \mathrm{ml}), \mathrm{CA} 12520$ $\mathrm{U} / \mathrm{ml}(\mathrm{N}<35 \mathrm{U} / \mathrm{ml}), \mathrm{CEA}<0,5 \mathrm{ng} / \mathrm{ml}(\mathrm{N}<3 \mathrm{ng} / \mathrm{ml}), \beta \mathrm{HCG}<5 \mathrm{U} / \mathrm{l}$ $(\mathrm{N}<5 \mathrm{U} / \mathrm{l}), \mathrm{LH} 16,5 \mathrm{mUl} / \mathrm{ml}(\mathrm{N}<5 \mathrm{mUl} / \mathrm{ml}), \mathrm{FSH} 102,0 \mathrm{mUl} / \mathrm{ml}(\mathrm{N}<$ $8 \mathrm{mUl} / \mathrm{ml})$, Estradiol 23,8 pg/ml, Androstenedione $1 \mathrm{ng} / \mathrm{ml}$ (Ref. 0,3 - 3,3 ng/ml), Total Testosterone $26,4 \mathrm{ng} / \mathrm{dl}(\mathrm{N}<20 \mathrm{ng} / \mathrm{dl})$, Free Testosterone $<0,5 \mathrm{pg} / \mathrm{ml}$, DHEA-SO 158,0 $\mu \mathrm{g} / \mathrm{dl}$ (Ref. 35 - $430 \mu \mathrm{g} / \mathrm{dl}$ ) e $17 \mathrm{a}-\mathrm{OH}$ - progesterona $1,9 \mathrm{ng} / \mathrm{ml}(\mathrm{N}<0,9 \mathrm{ng} / \mathrm{ml})$. Pelvic ultrasound: infantile uterus $(34,4 \times 11,3 \times 16 \mathrm{~mm})$. The hand and wrist $\mathrm{x}$ ray revealed a bone age of 13 years-old ( 14,5 years-old of chronological age).

The patient has started hormonal therapy with estradiol ( $1 \mathrm{mg} /$ day) at the age of 15 and the dose was adjusted to her breast development (final dose: $3 \mathrm{mg} /$ day). We added noretisterone $(1 \mathrm{mg} /$ day) when the breast development was completed. She has achieved an adult sexual development and the mid-parental height (+1 SD).

Presently she is 23 years-old and maintains follow up by an endocrinologist and an oncologist. From last evaluation: pelvic and breast ultrasounds without suspicious images and bone density with a T-score $-1,2$ in lumbar spine and $-0,2$ in femoral neck.

\section{Discussion}

PGD syndrome or Swyer syndrome is a rare condition that occurs with a frequency of approximately 5 of 100000 newborns [4]. It was first described in 1955 [5] and is applied to a particular variety of defective organogenesis, in which phenotypically female with a 46, XY karyotype have complete lack of functioning gonadal tissue [6]. The defect in organogenesis occurs during early embryonic development, when initially immature bi-potential gonads fail to differentiate along the male pathway. It can result from SRY deletions or point mutations, dosage sensitive sex locus duplication on $\mathrm{X}$ chromosome or mutations in autosomal genes [7].

SRY mutations account for approximately $10-20 \%$ of all cases of PGD [8-9]. The human SRY gene (Yp11.3) encodes a 204 amino acid protein that comprises three domains: $\mathrm{N}$-terminal, central (DNA binding) and C-terminal. The central domain contains 79 amino acids and is known as a High Mobility Group (HMG) box, which is found in a number of transcription factors [10-11]. Its main function is to actively divert development of the gonadal primordial towards male differentiation, pre-empting the alternative ovarian pathway [12]. It is possible towards the activation of SOX 9 gene, allowing differentiation of pre Sertoli cells (present in both sex) in Sertoli cells [13]. In the absence of SRY, SOX 9 becomes strongly down regulated in XX gonads [14]. Most SRY mutations are, de novo events affecting one family member, but 11 familial mutations have been described. All lie in HMG box. Six of the changes are missense mutations, three nonsense mutations and two deletions causing frameshifts [15]. Our patient has a microdeletion in Yp11.23 that eliminates the codifying sequence of SRY gene. Her father didn't have any microdeletion, which is suggestive of a de novo mutation.

Most patients are first diagnosed during puberty in the absence of menarche. Patients with this syndrome have female external genitalia, bilateral streak gonads, Mullerian duct development, sexual infantilism and eunuchoid habitus [3]. The majority of girls are thin with a normal or tall stature [16].

Hormonal analysis show high levels of androgens compared with that in normal females, whereas estrogens are absent or at a very low level. The lack of estrogens is responsible for the nondevelopment of the breast, non enlargement of the pelvis and hips and for the absence of menstruation [3]. Our patient had the de- scribed hormonal changes and her development was B1 and P3, which is consistent with the diagnosis. She had never gone to see a doctor because of the absence of menstruation or secondary sexual characters before she got ill. She was only 14 when dysgerminoma first manifested; at that age not all girls went through a complete pubertal development. Just after gonadobastomas, dysgerminoma is the second most frequent neoplasm in patients with pure dysgenesis. The frequency ranges between $30 \%$ to $75 \%$ in some series [17-18], but because the pure dysgenesis is a rare condition and almost all patients had their gonads removed it is difficult to estimate cancer risk.

Concerning to psychological aspects, most girls present great identity problems when they are diagnosed as genetically male at puberty, and although most of the patients are satisfied with their female gender, they are less likely to have sexual relationships and children [19]. Because in our case the dysgerminoma was found before the diagnosis of pure dysgenesis was made, our patient never asked about her karyotype and genetic analysis. She has a normal sexual life and manifests hope in being a mother, even though she knows allogenic oocytes will be necessary.

The treatment of $46, X Y$ DSD patients requires an appropriately trained multidisciplinary approach. The purpose of the hormonal therapy is the development of female sexual characteristics and induction of menses. The treatment must stimulate normal puberty. Low doses of estrogens are introduced at $9-11$ years old to prevent excessive bone maturation. After breast development is complete, adult estrogen doses are maintained continuously and a progesterone formulation is added to induce menses [7]. As our patient came to us when she was 14 years-old, we started hormonal therapy with $1 \mathrm{mg}$ of estradiol (B 1) and the doses had been titrated to 3 $\mathrm{mg} /$ day according to the breast development. She started combined therapy with 19 years-old with $2 \mathrm{mg}$ of estradiol and $1 \mathrm{mg}$ of noretisterona acetate, underwent regular normal menstrual cycles.

The oestrogen dose should be titrated according to the symptoms control and bone density requirements [20]. Our patient has no symptoms of ovarian failure and her bone density shows neither osteopenia nor osteoporosis. It is presumed that long-term use of hormonal therapy in physiological doses in this kind of patients does not increase the risk of breast cancer [20], but as long-term outcome data are needed to confirm this, we maintain a carefully vigilance of her breast, with annual ultrasounds.

This case shows the importance of a multidisciplinary approach to patients with Swyer syndrome, for prevention of gonadal neoplasms, to promote a normal pubertal development and psychosocial life, and assuring a correct follow-up for prevention complications of hormone replacement therapy and detect as early as possible, tumor recurrence.

Conflict of Interest: The authors declare no conflict of interest.

\section{References}

[1] Järger R.J., Anvret M., Hall K. \& Scherer G. (1990) Nature, 348, 452-454.

[2] Michala L., Goswami D., Creighton S. \& Conway G. (2008) BJOG: An International Journal of Obstetrics \& Gynaecology, 115(6), 737-741.

[3] Jorgensen P.B., Kjartansdóttir K.R. \& Fedder J. (2010) Fertility and Sterility, 94, 105-113. 
[4] Robinson A. \& Linden M.G. (1993) Ambiguous genitalia and hermaphroditism, Clinical genetic handbook, 2nd ed., Blacwell Scientific, Boston, 309-315.

[5] Swyer G.I. (1955) British Medical Journal, 2, 709-712.

[6] Guidozzi F., Ball J. \& Spurdle A. (1994) Obstetrical and Gynecological Survey, 49, 138-146.

[7] Mendonca B.B., Domenice S., Arnhold I.P. \& Costa E.M. (2009) Clinical Endocrinology, 70, 173-187.

[8] Hawkins J.R., Taylor A., Goodfellow P.N., Migeon C.J., Smith K.D. \& Berkivitz G.D. (1992) Am. J. Hum. Genet., 51, 979-984.

[9] Lim H.N., Freestone S.H., Romero D., Kwik C., Hughes I.A. \& Haekins J.R. (1998) Mol. Cell Endocrinol., 140, 51-58.

[10]Chomczyński P. (1993) Biotechniques, 3, 532-537.

[11]Cools M., Drop S.L., WolffenButtel J.W. \& Looijenga L.H. (2006) Dev. Biol., 274, 271-279.

[12]Sinclair A.H., Berta A., Palmer M.S., Hawkins J.R., Griffiths B.L., Smith M.J., Foster J.W., Frischauf A.M., Lovell-Badge R. \& Goodfellow P.N. (1990) Nature, 346, 240-244.

[13]Quinn A. \& Koopman P. (2012) Seminars in Reproductive Medicine, 30, 351-363.

[14]Wilhelm D., Martinson F., Bradford S., Wilson, M.J., Combes, A.N., Beverdam A., Bowles J., Mizusaki H. \& Koopman P. (2005) Dev. Biol., 287, 111-124.

[15]Hawkins J.R. (1993) Human Mutation, 2, 347-350.

[16]Ogata T. \& Matsuo N. (1993) Hum. Genet., 91, 551-562.

[17]Gallager H.S. \& Lewis R.P. (1973) Obstet. Gynecol., 41, 123128.

[18]Zielinska D., Zajaczek S. \& Rzepka-Gorska I. (2007) J. Pediatr. Surg., 42, 1721-1724.

[19]Jurgensen M., Hiort O., Holterhus P.M. \& Thyen U. (2007) Hormones and Behavior, 51, 443-453.

[20]Davis M. \& Cartwright B. (2012) Clinical Endocrinology, 77, 182 $-186$. 